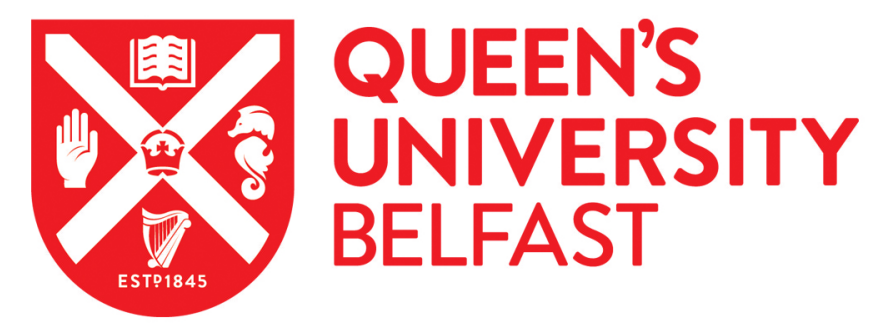

\title{
Dynamic conceptual framework to investigate adoption of healthy diet through agent-based modelling
}

Rahmani, J., Razaz, J. M., Kalantari, N., Garcia, L. M. T., Shariatpanahi, S. P., Bawadi, H., Thompson, J. Y., Ryan, P. M., Santos, H. O., \& Roudsari, A. H. (2021). Dynamic conceptual framework to investigate adoption of healthy diet through agent-based modelling. British Food Journal, 123(8), 2743-2755.

https://doi.org/10.1108/BFJ-09-2020-0828

Published in:

British Food Journal

Document Version:

Peer reviewed version

Queen's University Belfast - Research Portal:

Link to publication record in Queen's University Belfast Research Portal

\section{Publisher rights}

Copyright 2021 Emerald Publishing Limited.

This is an open access Creative Commons Attribution-NonCommercial License (https://creativecommons.org/licenses/by-nc/4.0/), which permits use, distribution and reproduction for non-commercial purposes, provided the author and source are cited.

\section{General rights}

Copyright for the publications made accessible via the Queen's University Belfast Research Portal is retained by the author(s) and / or other copyright owners and it is a condition of accessing these publications that users recognise and abide by the legal requirements associated with these rights.

Take down policy

The Research Portal is Queen's institutional repository that provides access to Queen's research output. Every effort has been made to ensure that content in the Research Portal does not infringe any person's rights, or applicable UK laws. If you discover content in the Research Portal that you believe breaches copyright or violates any law, please contact openaccess@qub.ac.uk. 


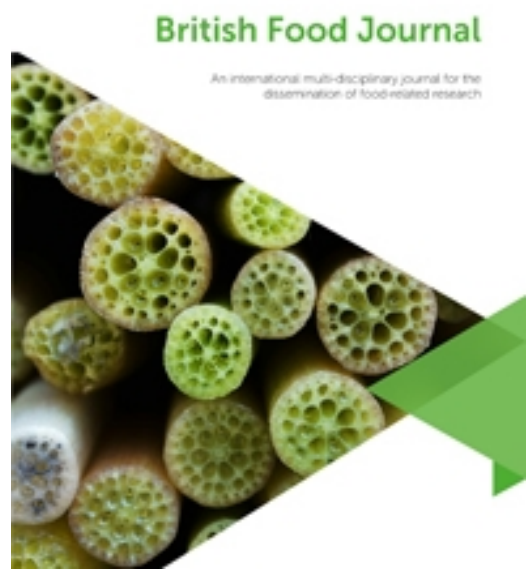

Dynamic conceptual framework to investigate adoption of healthy diet through agent-based modelling

\begin{tabular}{|r|l|}
\hline Journal: & British Food Journal \\
\hline Manuscript ID & BFJ-09-2020-0828.R2 \\
\hline Manuscript Type: & Research Paper \\
\hline Keywords: & Customer behaviour, Behaviour, Diet, food consumption \\
\hline \multicolumn{2}{|l}{} \\
\end{tabular}

SCHOLARONE ${ }^{\text {TM }}$

Manuscripts 
Dynamic conceptual framework to investigate adoption of healthy diet through agentbased modelling 


\begin{abstract}
Purpose: The purpose of this research is to develop a dynamic conceptual framework depicting factors related to the adoption of a healthy diet, which will underpin the development of an agentbased model to uncover the dynamic interplay between these factors.

Design/methodology/approach: The conceptual framework was developed in three steps using available empirical data from semi-structured in-depth interview qualitative study, a comprehensive systematic literature searches, existing theories and models, and expert opinions from across the world.
\end{abstract}

Findings: The conceptual framework explicitly presents intention as the key determinant of the tendency to adopt a healthy diet. Intention is determined by demographic, psychological and behavioural factors, and individual dietary mind-set factors, and dynamically affected by social environment and the person's past behaviour. The relationship between intention and behaviour is dynamically moderated by perceived control factors (price and accessibility of healthy food, and time).

Originality: The conceptual framework developed in this study is well supported by evidence and experts' opinions. This conceptual framework will be used to design our agent-based model, and it can be used in future investigations on the tendency to adopt healthy diet and food choices.

Keywords: Agent-based model, Conceptual framework, Food choices, Healthy diet. 


\section{Introduction}

Unhealthy eating has been identified by the World Health Organization (WHO) as a significant risk factor for non-communicable diseases (NCDs) including cancer, cardio-metabolic diseases and obesity (Organization, 2016). A Lancet report indicated strong links between poor diet and mortality, accounting for 1 in 5 deaths globally (Afshin, et al., 2019). In 2015, NCDs accounted for 40 million deaths worldwide, $80 \%$ of which could be prevented (Organization, 2016).

A healthy diet is usually defined as a diet that is high in plant-based foods such as whole grains, fruits, vegetables, nuts, legumes, and fish and low in high-fat and processed animal-based food (Organization, 2019). Basic principles of healthy eating include variety, caloric control, reduced salt, sugars, saturated and trans-fats consumption. Despite the large amount of research on factors influencing healthy eating, only small improvements in health diet are observed at the population level worldwide ( $\mathrm{Ng}$, et al., 2014). Furthermore, the dynamic interaction between these factors and sustained effects are poorly understood. Understanding the factors influencing the adoption of a healthy diet and their dynamic relationships is essential to promote health and prevent diseases.

The inter-relations between the factors influencing the adoption of a healthy diet are complex. Recently, the use of computational models to simulate the effect and interactions of factors influencing health outcomes- such as the adoption of a healthy diet- has received growing attention. For example, there is an increased interest in applying agent-based model (ABMs) better to understand complex public health matters (Tracy, et al., 2018). The use of ABM allows a holistic understanding of dynamic interactions between factors at different levels (i.e., personal, behavioural, social, economic, and environmental factors) (Tracy, et al., 2018). ABM has been applied to public health understand the multiple drivers of population patterns of health 
behaviours related to the risk of NCDs such as smoking cessation (Beheshti \& Sukthankar, 2014), alcohol drinking (Gorman, et al., 2006), and physical activity(L. M. Garcia, et al., 2018).

There are several other ABMs that have addressed the issue of a healthy diet (Auchincloss, et al., 2011; Beheshti, et al., 2016; Langellier, 2016; Orr, et al., 2014; Rice, 2012). But limited number of them provide a conceptual framework for their study. So it is needed to a developable conceptual framework in the context of a healthy diet. Furthermore, each of the previous studies examined a specific aspect of the factors that influence and shape the diet such as social networks(Langellier, 2016; Orr, et al., 2014), spatial disparities(Rice, 2012), price per calorie(Beheshti, et al., 2016), and income (Auchincloss, et al., 2011). Studies have not paid enough attention to personal factors such as psychological and demographic factors and have paid less attention to dietary-mind factors such as dietary knowledge, attitude and self-efficacy. Our work tries to fill this gap by designing a comprehensive conceptual framework combining, in a structured way, a comprehensive review of literature and expert opinions. This design includes psychological and behavioural factors, dietary-mind, demographic, perceived control and social environment factors that affected healthy dietary choices. This paper reports the development of the dynamic conceptual framework depicting the factors related to the adoption of a healthy diet that underpin our ABM.

\section{Methods}

Our endpoint is to construct an $\mathrm{ABM}$ of the determinants and mechanisms that shape the tendency to make healthy food choices as well as the decision-making involved during this process in the context of community-dwelling healthy individuals. To underpin the ABM, a conceptual framework was developed in a three-stage approach (Figure 1), as proposed by Garcia et al.(L. M. T. Garcia, et al., 2017). An initial model was developed based on the authors' expertise and a 
qualitative study that was carried out by authors, details of which have been reported elsewhere (Haghighian Roudsari, et al., 2017; Haghighian Roudsari, et al., 2019). As a second step, an intermediary conceptual framework was developed by updating the conceptual framework using new information obtained from a comprehensive literature search in MEDLINE, Scopus and Web of Science. Subsequently, a panel of international expert researchers in this field assessed the intermediary conceptual framework, and a final revised version of the conceptual framework was formulated.

\section{Initial conceptual framework}

The initial model was developed using the Theory of Planned Behaviour (TPB) (Ajzen, 1991), a widely applied theory in food choices and healthy eating behavioural research (Canova, et al., 2020; Ehrlinger, et al., 2017; Petrovici, et al., 2004; Vilaro, et al., 2016). We applied TPB as a foundation of our model and developed it using the expertise of the study authors and a qualitative study of determinants of food choice that was carried out by authors using a semistructured in-depth interview, details of which have been reported elsewhere (Haghighian Roudsari, et al., 2017; Haghighian Roudsari, et al., 2019). Briefly, 33 adults living in Tehran took part in in-depth semi-structured interviews that explored factors influencing food choice with a focus on perception, attitude, and eating practices (Haghighian Roudsari, et al., 2017; Haghighian Roudsari, et al., 2019).

\section{Intermediary model of conceptual framework}


An intermediary conceptual framework was subsequently developed by updating the initial model using additional information derived through a systematic search of the literature. This stage aimed to consolidate, remove or include elements and relationship into the initial conceptual framework. Following recommendations for evidence-based practice (Evans, 2003; Murad, et al., 2016), we limited our literature search to meta-analysis and systematic reviews to ensure findings on efficacy were used to inform the design of our framework. We conducted a comprehensive systematic search without language, location, or time restrictions in PubMed/MEDLINE, Scopus and Web of Science databases up to the $10^{\text {th }}$ February of 2020 . We used MeSH and non-MeSH keywords in titles, abstracts, and keywords for literature search limited to systematic reviews and meta-analysis (Table S1). Furthermore, in an attempt to avoid exclusion of other relevant studies, reference lists of included studies were screened, and an email alert was put in place to detect studies of interest after the date of the search. Finally, the intermediary conceptual framework was developed by reviewing selected original empirical studies and theories that helped to define constructs and delimit the elements, relations, and mechanisms.

\section{Final model of conceptual framework}

The final version of the conceptual framework was developed considering opinions of expert from around the world. To achieve an adequate volume of responses, we set out to obtain the opinions of at least twenty experts in different fields. The response rate was anticipated to be around $20 \%$, thus 100 experts were invited to evaluate the intermediary model. Invited experts were mostly identified and selected during the literature review step and were from multiple fields such as community nutrition, epidemiology, sociology and psychology. The professional webpage or curriculum vitae of invited experts were searched to obtain information to describe the 
participants, such as gender, country, and fields of expertise. An electronic link containing the intermediary framework alongside a description of the project's purpose, goals and delimitations was sent by email to experts. Four questions were posed to experts to evaluate the intermediary model:

One question was presented with response options in a five-point Likert scale from 1 (completely disagree) to 5 (completely agree):

I) How much do you agree with the current intermediary conceptual model?

The other three questions had an open-ended format:

I. Are there any variables or mechanisms not included in the current intermediary conceptual model that should be added?

II. Are there any variables or mechanisms included in the current intermediary conceptual model that should be excluded?

III. Do you have any additional comments or suggestions about the current intermediary conceptual model?

Four weeks were given for experts to express their opinions, and a reminder email was sent to them at the end of the third week. The first author reviewed, categorised and coded all experts' responses based on content similarity. Suggestions on elements and process were used to help decide whether variables and mechanisms should be kept, added or ignored from the intermediary conceptual framework. We ranked and prioritised the frequencies of suggestions on elements and process. Those that were outside the scope of our ABM or the aim of this study were not incorporated in the model. 
The expert consultation was approved by the Ethics in Research Committee of the National Nutrition \& Food Technology Research Institute, Iran (\# IR.SBMU.NNFTRI.REC.1398.069).

\section{Results}

The initial conceptual framework is shown in Supplementary Figure S1. It incorporated individual, social, food, and environmental factors. Besides the TPB, features and elements of social practice theories(Ortner, 2006), social cognitive theory(Bandura, 2001), random utility models(Baltas \& Doyle, 2001), and food choice process model (T. Furst, et al., 1996) were also taken into account in the design of this initial conceptual framework. The structure of the initial conceptual framework builds on the TPB. In the first step, we listed affective variables according to author's knowledge and classified them into categories of final behaviour, intention, perceived behaviour control related to food, subjective norms and environmental factors, and attitude containing socio-economic, psychological and knowledge factors.

The systematic literature search conducted to build the intermediary version of the framework yielded 2589 papers, of which 1007 were duplicates and 1524 irrelevant records were excluded following title, abstract or full-text review (Figure 2). Fifty-eight studies were eligible and underwent in-depth review (see Table S2 for main findings of each paper). Elements and process identified within the 58 eligible studies were used to change and improve our initial conceptual framework (Supplementary Figure S2). We identified food price (Andreyeva, et al., 2010; Bennett, et al., 2020; Mogendi, et al., 2016) and food access (Abeykoon, et al., 2017; Akande, et al., 2015; Gittelsohn, et al., 2017; Pitt, et al., 2017) as key perceived controls in determining healthy dietary behaviours, while individual factors (McDermott, et al., 2015; Nardi, 
et al., 2019; Riebl, et al., 2015), social environment (Allan, et al., 2017; McDermott, et al., 2015), and past behaviour (Nardi, et al., 2019) were identified as determinants of intention. Past behaviour appears to have an effective role in determining intention (Nardi, et al., 2019), while the social and physical environments have different roles in the framework (Clohessy, et al., 2019; Fletcher, et al., 2011; Pitt, et al., 2017; Vecchio \& Cavallo, 2019; Wright \& Bragge, 2018). Physical environment (access) in the perceived control box has a modifying role on the effect of intention upon behaviour function (Abeykoon, et al., 2017; Akande, et al., 2015; Pitt, et al., 2017), whereas social environment is affected by past behaviour and have direct effect on intention (Nardi, et al., 2019). In developing the intermediary conceptual framework, economic level (De Irala-Estevez, et al., 2000; Kamphuis, et al., 2015) and influence of past behaviour (Nardi, et al., 2019) were added to the model.

Of the 100 invited experts, 23 completed the survey form, of which $43 \%$ were male. Experts were from a variety of fields: Nutritional Epidemiology, Public Health and Nutrition (Community nutrition), Epidemiology, Consumer Behavior, Food Policy, Psychology, Marketing, Health Economics, Public Health, Sociology, Chronic Disease Care, and Social Anthropology. Their regions of practice were the US, the UK, Denmark, Australia, Brazil, Canada, Italy, Qatar, China, France, India, New Zealand, Iran, and Kenya. The mean score of agreement with the conceptual framework was $3.70 \pm 0.82$, and three of the experts were entirely in agreement with the proposed conceptual framework.

The feedback provided by experts on the intermediary conceptual framework is outlined in Table S3. The most common comments were about: 1) adding self-efficacy as an important factor in food choice and following a healthy diet; 2) considering the effect of advertising; 3) the effect of food choice on disease and health status of family members; 4) attention to health literacy, 
self-esteem and knowledge, and 5) time as a perceived control factor. The frequency of proposed comments is provided is supplementary Figure S3. Attention to social environment and norms was emphasized by $30 \%$ of participants. Furthermore, $26 \%$ of the experts proposed to add selfefficacy to the conceptual framework. Intention was mentioned by $26 \%$ of participants. Past behaviour, health status, and economic level were proposed by $13 \%$, and time to providing a healthy diet by $9 \%$ of researchers. Only $4 \%$ of the experts suggested the addition of self-esteem.

In the last stage, the conceptual framework was updated to incorporate the experts' opinions. We included time and self-esteem in the final conceptual framework. Also, we added healthy diet-related knowledge, attitude, and self-efficacy (individual dietary mind-set factors) factors to the model, which encompass health literacy and advertising. In fact, advertising can indirectly change the intention of behaviour by affecting dietary mind-set factors. There were no many suggestions to exclude elements or relationships. All changes in the elements and relationships through each iteration of the conceptual framework are displayed in Table S4.

The resulting conceptual framework is presented in Figure 3, and the relevant operational definition of the elements included is provided in Table 1. The meanings and assumptions of the relationships in the conceptual framework are presented in Table 2. In this conceptual framework, the influence of an individual's past behaviour and social environment on intention is considered to have an inverted $U$ shape. That is to say that the closer the intention is to its upper or lower limit, the weaker the influence of the individual's past behaviour and the social environment on his or her current intention. Furthermore, perceived controls are deemed to have a moderating effect on the relationship between intention and behaviour (i.e., likelihood of adopting a healthy diet) (Figure 4).

Discussion 
This study aimed to construct a dynamic conceptual framework of healthy eating behaviour, which will form the foundations for and inform an $\mathrm{ABM}$. This framework was derived from a three-stage development process involving a qualitative study of healthy eating behaviours, a systematic overview of published systematic reviews, and finally, refinement of proposed factors and relationships through the incorporation of expert opinion. The framework identifies key personal, environmental, and perceived control which dictate the likelihood of an individual to adopt a healthy diet. Furthermore, we attempted to define and describe the direction and nature of each relationship; all of which is intended to inform the creation of an ABM and allow in-depth interrogation of the determinants and their associations.

The conceptual framework we developed contains important elements, and mechanisms of existing theories on food choice such as (a) economic (household and random utility) models (Baltas \& Doyle, 2001; Bonke, 1992), (b) food choice process model (Tanis Furst, et al., 1996) and (c) TPB (Ajzen, 1991; Conner \& Armitage, 2006; Fishbein \& Ajzen, 1980; McCarthy, et al., 2003). This conceptual framework contains important features of complex systems approaches such as dynamic mechanisms linking between elements, dynamic perspective on the phenomenon, feedback loops behaviour and its causes, emergent behaviours, limited predictability, dynamic actions between interdependent individuals, and fundamental uncertainty (Bar-Yam, 2002; Cameron \& Larsen-Freeman, 2007; Grimm, et al., 2005). Interestingly, Sobal and Bisogni, employing constructionist social definition perspectives to promote a food choice process model, linked food choice strategies to intuitive responses that establish factors and dynamics involved in food behaviours(Sobal \& Bisogni, 2009). More specifically, for this food choice process, the authors considered life course events and experiences, cultural ideals, personal factors, resources, social factors, and food choice strategies in the individual routine(Sobal \& Bisogni, 2009). 
In 1996, Furst et al. proposed one step toward an more complete understanding of food choice, suggesting that a constructionist approach can positively impact the food choice(Tanis Furst, et al., 1996). In 1999, Shepherd highlighted the importance of TPB as a model from social psychology for predicting behaviour as well as a tool to determine the relevance of various factors in influencing food choice(Shepherd, 1999). Among the plethora of extensions of this model, the moral obligation is a way to expanding factors related to food choices in specific scenarios(Shepherd, 1999). Taking into account these proposals, further consideration should be given to emotional and feeling elements fundamental in food choice, instead of trivially considering food choice as a rational cognitive problem(Shepherd, 1999). Indeed, TPB formed the basis for this framework, as well as the relationship between intention and behavior is among the highlights (Ajzen, 1991; Conner \& Armitage, 2006). Herein, such a relationship was deemed to be moderated by perceived controls such as healthy food price, accessibility, and time available to the individual. This perceived role may make such factors amenable to intervention and can be explored further through ABM. This interaction is highlighted in Figure 4, which demonstrates the potential beneficial or harmful modulatory effects of these perceived controls on the relationship between intention and behavior.

The process involved in developing this framework is a relatively novel one. It has been previously used to study patterns of leisure-time physical activity among community dwelling adults (L. M. T. Garcia, et al., 2017). In this study, each stage of the process resulted in a significant modification in the subcomponents of the framework, although without major shifts in key themes (i.e., environmental, individual, etc.) or their relationships. Evidence from the systematic review was incorporated into the framework, but no significant changes were made. We explicitly defined perceived controls as a category and confined their effect as solely on the transition from intention to behaviour. Finally, we incorporated the most common recommendations of experts, and further sub-classified individual factors into demographics, individual dietary mind-set factors, and psychological aspects in the final iteration of the framework. Although a range of additional factors were suggested and considered at each stage of the framework development, we aimed to create a 
highly parsimonious conceptual model. This meant that several potentially valid elements and relationships were excluded based on their relevance to the questions we expect to investigate with our ABM. However, excluded factors have been catalogued for consideration in future versions of the framework and ABM.

The findings of this article may provide a better understanding of the complex relationship between socio-economic and psychological factors and mechanisms that affect the adoption of a healthy diet. This paper provides a comprehensive conceptual model that takes into account the knowledge base of different fields that can bridge the gap between theory and practice in investigating the adoption of a healthy diet through ABM simulation.. As this model is a multifield conceptual framework developed with ABM in mind, researchers and policymakers can use it for simulating scenarios in an attempt to find the best policy to be implemented in the community and improve government policy in the prevention of NCDs. Insofar policies that improve community food habits and changing harmful eating habits and lifestyles are adopted, the risk of NCDs decreases. .

This work provides a framework that can assist in the adoption of healthy eating behavior, which is a dynamic and multifaceted problem that cannot be addressed satisfactorily through single-component strategies. While recognizing the scale of this problem, previous efforts to address a restricted number of factors or levels of influence independently have demonstrated significant shortcomings and failed to acknowledge the entire dynamic relationship. The application of a socio-ecological methodology should lead to a broader consideration and ultimately a complete assessment of different levels of influence, such as intrapersonal, interpersonal, environmental and policy factors, as well as the nature of their respective contributions. In addition, it should be empathized that global obesity trends continue to rise 
without effective, sustainable, or promising interventions for management ( $\mathrm{Ng}$, et al., 2014). We

hope that this conceptual framework and subsequent ABMs can contribute with in the primary prevention of obesity and related comorbidities (i.e., hypertension, metabolic syndrome, diabetes, and dyslipidemia), which is a key course of action against the mortality rates caused by these global concerns (Hoelscher, et al., 2015; Lutfiyya, et al., 2008; Padwal \& Sharma, 2010; van Grieken, et al., 2012).

\section{Strengths and Limitations}

In designing this framework, we drew upon lay-person, stakeholder and expert opinion, alongside up-to-date evidence from a comprehensive systematic review of published reviews. The integration of this diverse set of information is a significant strength of the current study and the resulting framework, which ensures its accuracy and generalizability. Also, the heterogeneity between the fields of the experts improved the comprehensiveness of the final conceptual framework. Furthermore, this conceptual framework provides a good basis for future work by other researchers to expand and modify accordingly. More importantly, our multilevel framework was designed to be suitable for the development of ABMs, while other existent models are neither multilevel nor appropriate for ABM.

On the other hand, there were some limitations that should be pointed out. First, the low response rate of experts contacted suggests that non-responder bias may affect the quality of the opinions. However, the broad range of sub-specialties represented by the respondents is reassuring, indicating that the expert input was diverse and comprehensive. Another limitation is that the thematic synthesis of survey findings was performed by a single author without input from independent coding. Lastly, some relevant elements and mechanisms were not considered or included because there was no review about them yet. 


\section{Conclusion}

This study combined evidence from qualitative and quantitative sources to create a dynamic conceptual framework which aims to inform and support the creation of an ABM of healthy eating behaviour. Once validated through external data, we will be able to explore population patterns and various scenarios, thereby informing potential population-wide interventions for healthy eating behaviours.

\section{References:}

Abeykoon, A. H., Engler-Stringer, R., \& Muhajarine, N. (2017). Health-related outcomes of new grocery store interventions: a systematic review. Public Health Nutr, 20, 2236-2248.

Afshin, A., Sur, P. J., Fay, K. A., Cornaby, L., Ferrara, G., Salama, J. S., et al. (2019). Health effects of dietary risks in 195 countries, 1990-2017: a systematic analysis for the Global Burden of Disease Study 2017. The Lancet, 393, 1958-1972.

Ajzen, I. (1991). The theory of planned behavior. Organizational behavior and human decision processes, $50,179-211$.

Akande, V. O., Hendriks, A. M., Ruiter, R. A., \& Kremers, S. P. (2015). Determinants of dietary behavior and physical activity among Canadian Inuit: a systematic review. Int J Behav Nutr Phys Act, 12, 84.

Allan, J. L., Querstret, D., Banas, K., \& de Bruin, M. (2017). Environmental interventions for altering eating behaviours of employees in the workplace: a systematic review. Obesity Reviews, 18 , 214-226.

Andreyeva, T., Long, M. W., \& Brownell, K. D. (2010). The impact of food prices on consumption: a systematic review of research on the price elasticity of demand for food. Am J Public Health, $100,216-222$.

Auchincloss, A. H., Riolo, R. L., Brown, D. G., Cook, J., \& Roux, A. V. D. (2011). An agent-based model of income inequalities in diet in the context of residential segregation. American journal of preventive medicine, 40, 303-311.

Baltas, G., \& Doyle, P. (2001). Random utility models in marketing research: a survey. Journal of Business Research, 51, 115-125.

Bandura, A. (2001). Social cognitive theory: An agentic perspective. Annual review of psychology, 52, 126.

Bar-Yam, Y. (2002). General features of complex systems. Encyclopedia of Life Support Systems (EOLSS), UNESCO, EOLSS Publishers, Oxford, UK, 1.

Beheshti, R., Igusa, T., \& Jones-Smith, J. (2016). Simulated models suggest that price per calorie is the dominant price metric that low-income individuals use for food decision making. The Journal of nutrition, 146, 2304-2311. 
Beheshti, R., \& Sukthankar, G. (2014). A normative agent-based model for predicting smoking cessation trends. In Proceedings of the 2014 international conference on Autonomous agents and multiagent systems (pp. 557-564): Citeseer.

Bennett, R., Zorbas, C., Huse, O., Peeters, A., Cameron, A. J., Sacks, G., et al. (2020). Prevalence of healthy and unhealthy food and beverage price promotions and their potential influence on shopper purchasing behaviour: A systematic review of the literature. Obes Rev, 21, e12948.

Bonke, J. (1992). Choice of foods: allocation of time and money, household production and market services: MAPP Copenhagen.

Cameron, L., \& Larsen-Freeman, D. (2007). Complex systems and applied linguistics. International journal of applied linguistics, 17, 226-239.

Canova, L., Bobbio, A., \& Manganelli, A. M. (2020). Predicting fruit consumption: A multi-group application of the Theory of Planned Behavior. Appetite, 145, 104490.

Clohessy, S., Walasek, L., \& Meyer, C. (2019). Factors influencing employees' eating behaviours in the office-based workplace: A systematic review. Obesity Reviews, 20, 1771-1780.

Conner, M., \& Armitage, C. J. (2006). Social psychological models of food choice. Frontiers in nutritional science, 3, 41.

De Irala-Estevez, J., Groth, M., Johansson, L., Oltersdorf, U., Prättälä, R., \& Martínez-González, M. A. (2000). A systematic review of socio-economic differences in food habits in Europe: consumption of fruit and vegetables. European journal of clinical nutrition, 54, 706-714.

Ehrlinger, J., Burnette, J. L., Park, J., Harrold, M. L., \& Orvidas, K. (2017). Incremental theories of weight and healthy eating behavior. Journal of Applied Social Psychology, 47, 320-330.

Evans, D. (2003). Hierarchy of evidence: a framework for ranking evidence evaluating healthcare interventions. Journal of clinical nursing, 12, 77-84.

Fishbein, M., \& Ajzen, I. (1980). Understanding attitudes and predicting social behavior.

Fletcher, A., Bonell, C., \& Sorhaindo, A. (2011). You are what your friends eat: Systematic review of social network analyses of young people's eating behaviours and bodyweight. Journal of Epidemiology and Community Health, 65, 548-555.

Furst, T., Connors, M., Bisogni, C. A., Sobal, J., \& Falk, L. W. (1996). Food choice: a conceptual model of the process. Appetite, 26, 247-266.

Furst, T., Connors, M., Bisogni, C. A., Sobal, J., \& Falk, L. W. (1996). Food choice: a conceptual model of the process. Appetite, 26, 247-265.

Garcia, L. M., Roux, A. V. D., Martins, A. C., Yang, Y., \& Florindo, A. A. (2018). Exploring the emergence and evolution of population patterns of leisure-time physical activity through agent-based modelling. International Journal of Behavioral Nutrition and Physical Activity, 15, 112.

Garcia, L. M. T., Diez Roux, A. V., Martins, A. C. R., Yang, Y., \& Florindo, A. A. (2017). Development of a dynamic framework to explain population patterns of leisure-time physical activity through agent-based modeling. Int J Behav Nutr Phys Act, 14, 111.

Gittelsohn, J., Trude, A. C. B., \& Kim, H. (2017). Peer Reviewed: Pricing Strategies to Encourage Availability, Purchase, and Consumption of Healthy Foods and Beverages: A Systematic Review. Preventing chronic disease, 14.

Gorman, D. M., Mezic, J., Mezic, I., \& Gruenewald, P. J. (2006). Agent-based modeling of drinking behavior: a preliminary model and potential applications to theory and practice. American journal of public health, 96, 2055-2060.

Grimm, V., Revilla, E., Berger, U., Jeltsch, F., Mooij, W. M., Railsback, S. F., et al. (2005). Pattern-oriented modeling of agent-based complex systems: lessons from ecology. science, 310, 987-991.

Haghighian Roudsari, A., Vedadhir, A., Amiri, P., Kalantari, N., Omidvar, N., Eini-Zinab, H., et al. (2017). Psycho-socio-cultural determinants of food choice: a qualitative study on adults in social and cultural context of Iran. Iranian journal of psychiatry, 12, 241. 
Haghighian Roudsari, A., Vedadhir, A., Rahmani, J., \& Milani Bonab, A. (2019). Explaining the barriers and facilitators of ethnic and traditional food choices from the viewpoints of women. Journal of Ethnic Foods, 6, 33.

Hoelscher, D. M., Butte, N. F., Barlow, S., Vandewater, E. A., Sharma, S. V., Huang, T., et al. (2015). Incorporating primary and secondary prevention approaches to address childhood obesity prevention and treatment in a low-income, ethnically diverse population: study design and demographic data from the Texas Childhood Obesity Research Demonstration (TX CORD) study. Childhood obesity, 11, 71-91.

Kamphuis, C. B. M., Jansen, T., Mackenbach, J. P., \& Van Lenthe, F. J. (2015). Bourdieu's cultural capital in relation to food choices: A systematic review of cultural capital indicators and an empirical proof of concept. PLOS ONE, 10.

Langellier, B. A. (2016). An agent-based simulation of persistent inequalities in health behavior: Understanding the interdependent roles of segregation, clustering, and social influence. SSMpopulation health, 2, 757-769.

Lutfiyya, M. N., Nika, B., Ng, L., Tragos, C., Won, R., \& Lipsky, M. S. (2008). Primary prevention of overweight and obesity: an analysis of national survey data. Journal of general internal medicine, 23, 821-823.

McCarthy, M., de Boer, M., O'Reilly, S., \& Cotter, L. (2003). Factors influencing intention to purchase beef in the Irish market. Meat science, 65, 1071-1083.

McDermott, M. S., Oliver, M., Svenson, A., Simnadis, T., Beck, E. J., Coltman, T., et al. (2015). The theory of planned behaviour and discrete food choices: A systematic review and meta-analysis. International Journal of Behavioral Nutrition and Physical Activity, 12.

Mogendi, J. B., De Steur, H., Gellynck, X., \& Makokha, A. (2016). Consumer evaluation of food with nutritional benefits: a systematic review and narrative synthesis. Int J Food Sci Nutr, 67, 355-371.

Murad, M. H., Asi, N., Alsawas, M., \& Alahdab, F. (2016). New evidence pyramid. Evidence Based Medicine, 21, 125-127.

Nardi, V. A. M., Jardim, W. C., Ladeira, W., \& Santini, F. (2019). Predicting food choice: a meta-analysis based on the theory of planned behavior. British Food Journal, 121, 2250-2264.

$\mathrm{Ng}$, M., Fleming, T., Robinson, M., Thomson, B., Graetz, N., Margono, C., et al. (2014). Global, regional, and national prevalence of overweight and obesity in children and adults during 1980-2013: a systematic analysis for the Global Burden of Disease Study 2013. Lancet, 384, 766-781.

Organization, W. H. (2016). Global health Observatory (GHO) data: Noncommunicable diseases (NCD). In.

Organization, W. H. (2019). Healthy diet. In: World Health Organization. Regional Office for the Eastern Mediterranean.

Orr, M. G., Galea, S., Riddle, M., \& Kaplan, G. A. (2014). Reducing racial disparities in obesity: simulating the effects of improved education and social network influence on diet behavior. Annals of epidemiology, 24, 563-569.

Ortner, S. B. (2006). Anthropology and social theory: Culture, power, and the acting subject: Duke University Press.

Padwal, R. S., \& Sharma, A. M. (2010). Prevention of cardiovascular disease: obesity, diabetes and the metabolic syndrome. Canadian Journal of Cardiology, 26, 18C-20C.

Petrovici, D. A., Ritson, C., \& Ness, M. (2004). The theory of reasoned action and food choice insights from a transitional economy. Journal of International Food and Agribusiness Marketing, 16, 5987.

Pitt, E., Gallegos, D., Comans, T., Cameron, C., \& Thornton, L. (2017). Exploring the influence of local food environments on food behaviours: a systematic review of qualitative literature. Public Health Nutr, 20, 2393-2405. 
Rice, K. (2012). The Utility of Multilevel Modeling vs. Agent-Based Modeling in Examining Spatial Disparities in Diet and Health: The Case of Food Deserts. In Simulation for Policy Inquiry (pp. 6382): Springer.

Riebl, S. K., Estabrooks, P. A., Dunsmore, J. C., Savla, J., Frisard, M. I., Dietrich, A. M., et al. (2015). A systematic literature review and meta-analysis: The Theory of Planned Behavior's application to understand and predict nutrition-related behaviors in youth. Eat Behav, 18, 160-178.

Shepherd, R. (1999). Social determinants of food choice. Proceedings of the Nutrition Society, 58, 807812.

Sobal, J., \& Bisogni, C. A. (2009). Constructing food choice decisions. Annals of Behavioral Medicine, 38, s37-s46.

Tracy, M., Cerdá, M., \& Keyes, K. M. (2018). Agent-based modeling in public health: current applications and future directions. Annual review of public health, 39, 77-94.

van Grieken, A., Ezendam, N. P., Paulis, W. D., van der Wouden, J. C., \& Raat, H. (2012). Primary prevention of overweight in children and adolescents: a meta-analysis of the effectiveness of interventions aiming to decrease sedentary behaviour. International Journal of Behavioral Nutrition and Physical Activity, 9, 1-11.

Vecchio, R., \& Cavallo, C. (2019). Increasing healthy food choices through nudges: A systematic review. Food Quality and Preference, 78.

Vilaro, M. J., Staub, D., Xu, C., \& Mathews, A. E. (2016). Theory-Based Interventions for Long-Term Adherence to Improvements in Diet Quality: An In-depth Review. Am J Lifestyle Med, 10, 369376.

Wright, B., \& Bragge, P. (2018). Interventions to promote healthy eating choices when dining out: A systematic review of reviews. British Journal of Health Psychology, 23, 278-295. 
Figure 1. Steps for developing the conceptual framework.

Drafting Initial conceptual framework based on the initial expertise of all authors and results of qualitative study

Developing intermediary conceptual framework by revising the Initial conceptual framework using information obtained from literature review

Developing final conceptual framework by revising the intermediary conceptual framework using information obtained from expert survey results 
Figure 2. Flow chart of included studies identified in the literature search.

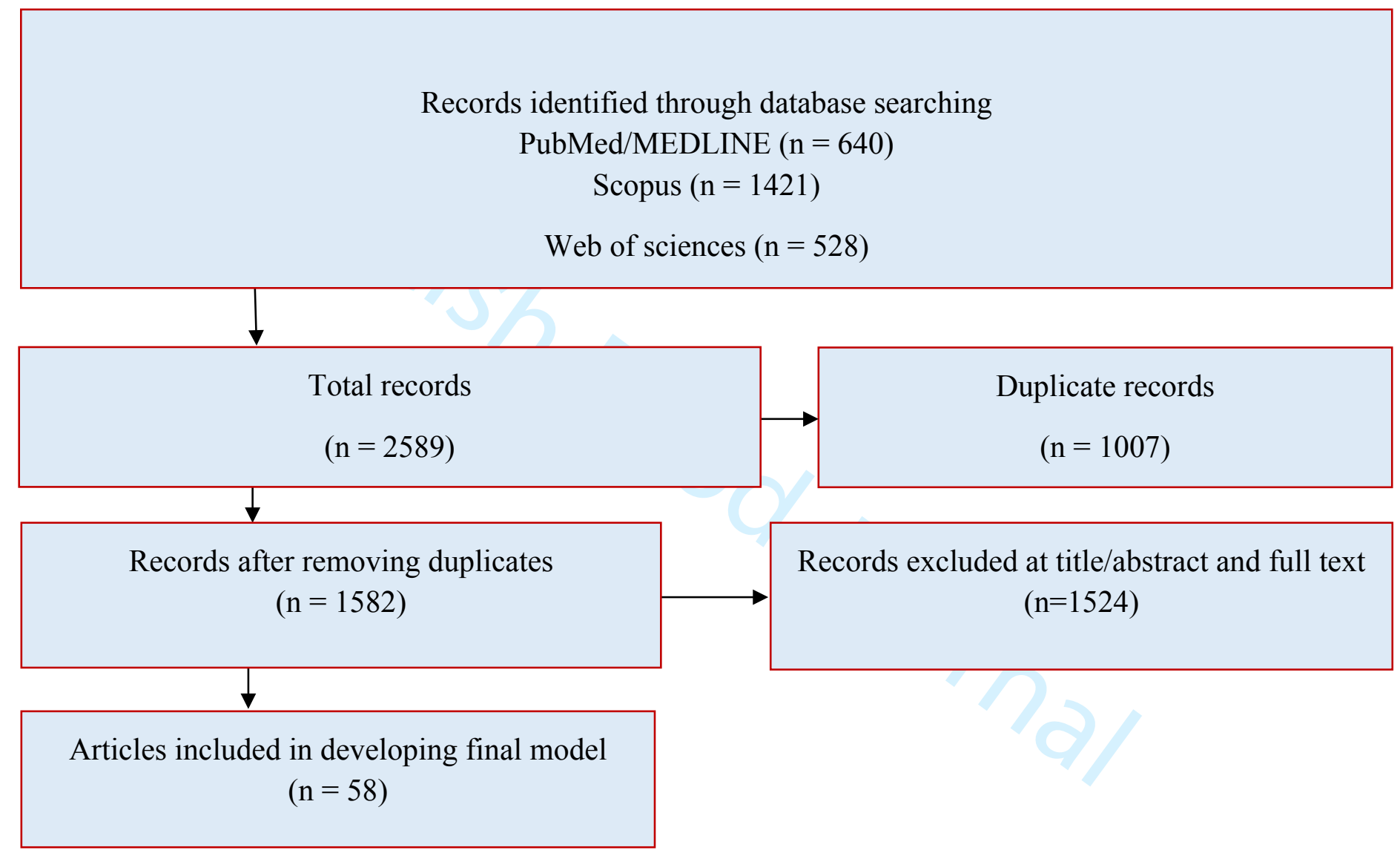


Figure 3. Dynamic conceptual framework of factors affecting the adoption of healthy diet.

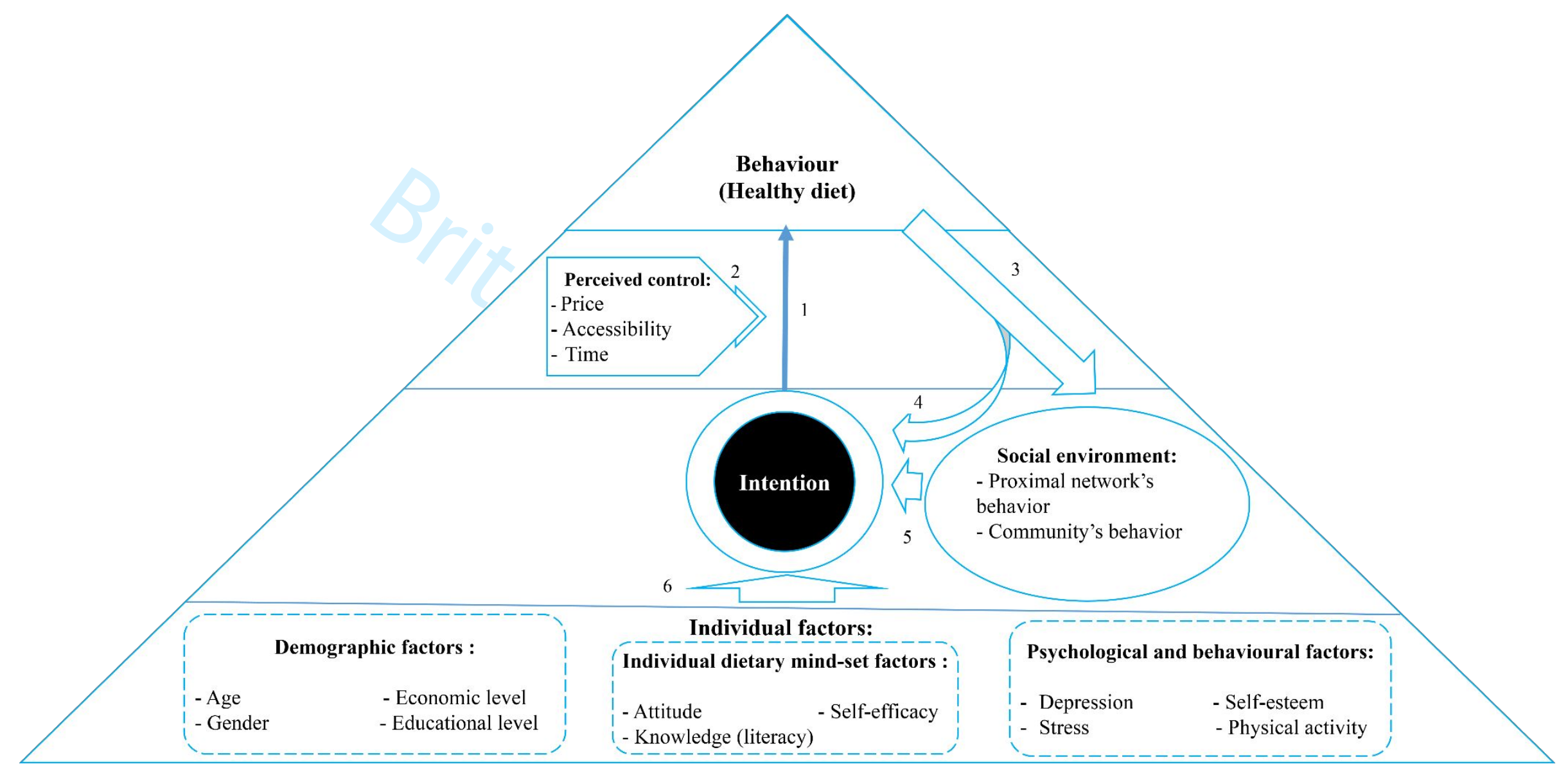


Figure 4. Example of the moderating effect of the perceived controls on the relationship between intention to adopt a healthy diet and the likelihood of following a healthy diet (Continuous line: relationship with no modification effect. Dotted and dashed lines: are relationships moderated by positive (dotted) or negative (dashed) perceived levels of control (Adapted from Garcia et al.2017)

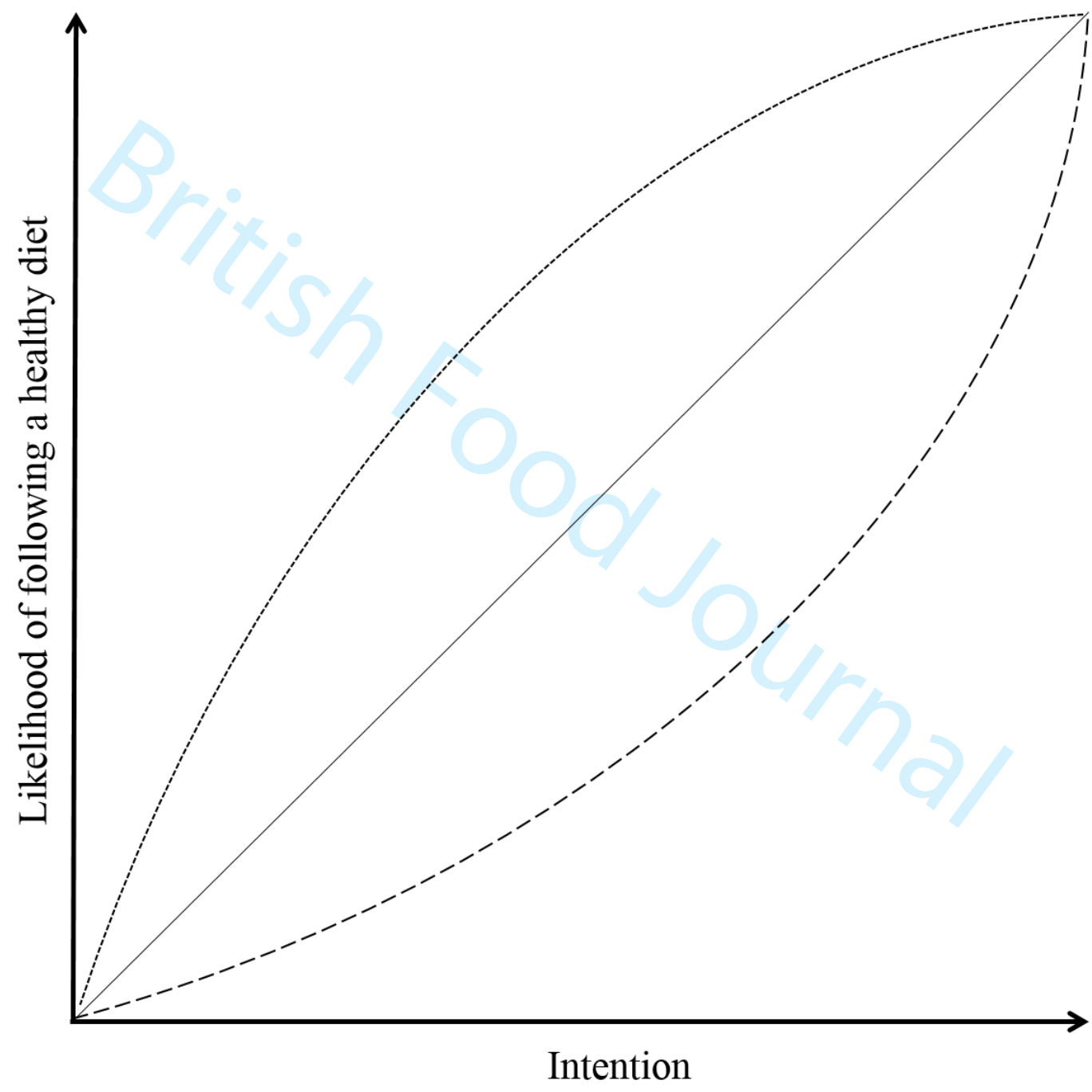


Table 1. Operational definition of the elements in the conceptual framework.

\begin{tabular}{|c|c|c|}
\hline Domain & Construct & Operational definition \\
\hline \multirow[t]{9}{*}{ Individual attributes } & Behaviour & Individual's healthy diet during a certain period of time \\
\hline & Intention & Effort of an individual to having a healthy diet \\
\hline & 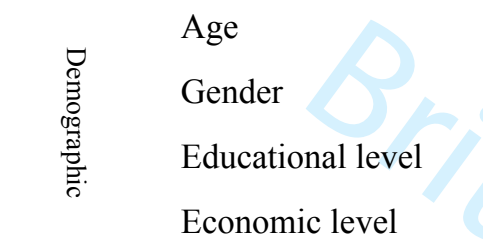 & \\
\hline & $\begin{array}{l}\text { Attitude } \\
\text { Knowledge } \\
\text { (nutritional literacy) }\end{array}$ & $\begin{array}{l}\text { A feeling or opinion about having a healthy diet } \\
\text { Knowledge of concepts and processes related to nutrition and health including knowledge of diet and health, diet } \\
\text { and disease, foods representing major sources of nutrients, and dietary guidelines and recommendations }\end{array}$ \\
\hline & Self-efficacy & One's ability to manage a healthy diet \\
\hline & Depression & Mood disorder that causes a persistent feeling of sadness and loss of interest. \\
\hline & Stress & Feeling of strain and pressure. \\
\hline & Self-esteem & An individual's subjective evaluation of their own worth \\
\hline & Physical activity & \\
\hline \multirow[t]{3}{*}{ Perceived control } & Price & Price of foods \\
\hline & Accessibility & How easily people can access and purchase healthy foods \\
\hline & Time & Having enough time to follow a healthy diet \\
\hline \multirow[t]{2}{*}{ Social environment } & Proximal network’s behaviour & Adherence to healthy diet of the people within the person's proximal network (friends, relatives etc.) \\
\hline & Community's behaviour & Adherence to healthy diet of people living in a relatively large and geographically limited area \\
\hline
\end{tabular}


Table 2. Meanings and assumptions of relationships contained in the conceptual framework.

\begin{tabular}{cl}
\hline Relationship & Meanings and assumptions \\
\hline 1 & $\begin{array}{l}\text { The intention of an individual determines his/her adoption of a healthy diet. The greater the intention, the more likely } \\
\text { is to adopt a healthy diet. }\end{array}$ \\
& $\begin{array}{l}\text { Moderating effect of the perceived controls on the relationship between intention and the likelihood of following a } \\
\text { healthy diet. Perceived controls strongly influence the relationship between intention and behaviour (see Figure 4). } \\
\text { The behaviour of the social environment (proximal network and community) are influenced by the individual's } \\
\text { behaviour. }\end{array}$ \\
& $\begin{array}{l}\text { The intention of an individual is influenced by his/her past behaviour. This relationship has an inverted U shape, i.e., } \\
\text { the closer the intention is to its upper or lower limit, the weaker the influence of the individual's past behaviour on } \\
\text { his/her current intention. }\end{array}$ \\
& $\begin{array}{l}\text { The intention of an individual is influenced by his/her social environment (proximal network and community). This } \\
\text { relationship has an inverted U shape, i.e., the closer the intention is to its upper or lower limit, the weaker the } \\
\text { influence of the social environment on his/her current intention. }\end{array}$ \\
& The intention of an individual is influenced by his/her intrinsic individual factors.
\end{tabular}




\section{Supplementary material}

Table S1. Keywords used in the literature search.

\begin{tabular}{|l|l|l|}
\hline PubMed/MEDLINE & Scopus & Web of sciences \\
\hline ((((((("Food Preferences"[Mesh] OR "Diet, & ( ( TITLE-ABS-KEY ( "meta-analysis" ) OR & TS=("eating behaviour" \\
Healthy"[Mesh]) OR "eating & TITLE-ABS-KEY ( "meta analysis" ) OR TITLE- & OR "Food Preferences" OR \\
behaviour"[Title/Abstract]) OR "Food & ABS-KEY ( "systematic review" ) OR TITLE-ABS- & "food choice*" OR "food \\
Preferences"[Title/Abstract]) OR "food & KEY ( "systematic-review" ) ) ) AND ( ( TITLE- & selection" OR "healthy \\
choice*"[Title/Abstract]) OR "food & ABS-KEY ( "eating behaviour" ) OR TITLE-ABS- & diet" OR "healthy eating" \\
selection"[Title/Abstract]) OR "healthy & KEY ( "Food Preferences" ) OR TITLE-ABS-KEY & OR "eat healthier") AND \\
diet"[Title/Abstract]) OR "healthy & ( "food choice*" ) OR TITLE-ABS-KEY ( "food & TS=("meta analysis" OR \\
eating"[Title/Abstract]) OR "eat & selection" ) OR TITLE-ABS-KEY ( "healthy diet" ) & "meta-analysis" OR \\
healthier"[Title/Abstract]) AND ((("meta & OR TITLE-ABS-KEY ( "healthy eating" ) OR & "systematic review" OR \\
analysis"[Title/Abstract] OR "meta- & TITLE-ABS-KEY ( "eat healthier" ) ) ) & \\
analysis"[Title/Abstract]) OR "systematic & & \\
review"[Title/Abstract]) OR "systematic- & & \\
review"[Title/Abstract]) & & \\
\hline
\end{tabular}


Table S2: Summary of findings from systematic reviews and meta-analysis retrieved from the literature search.

\begin{tabular}{|c|c|}
\hline Reference & Main findings \\
\hline $\begin{array}{l}\text { (Robson et al., } \\
2020)\end{array}$ & Positive association between family meal frequency and Healthy Eating Index. \\
\hline $\begin{array}{l}\text { (Bennett et al., } \\
2020)\end{array}$ & Price promotions of unhealthy foods may shift consumer purchasing ability towards cheaper choices. \\
\hline (Yang et al., 2019 & Training and education may influence eating behaviour. \\
\hline $\begin{array}{l}\text { (Vecchio et al., } \\
\text { 2019) }\end{array}$ & $\begin{array}{l}\text { Nudging approaches redirect consumer choice towards a healthier outcome and was successful in over } 80 \% \text { of } \\
\text { studies. Nudging involves modifying the physical or social context. }\end{array}$ \\
\hline (Tan et al., 2019) & $\begin{array}{l}\text { Stimulating sensory functions are negatively associated with food intake. Dietary behaviours are more related to } \\
\text { preferred appearance compared to sensitivity and intensity measures (taste). }\end{array}$ \\
\hline (Strahler, 2019) & Similar tendencies to a healthy diet between genders, although healthful eating is more pronounced in women. \\
\hline (Shaw et al., 2019 & Environmental interventions such as health promotion education and labelling improve dietary behaviours. \\
\hline (Sala et al., 2019) & $\begin{array}{l}\text { Mindfulness (bringing one's attention to present moment) is associated with eating health behaviours ( } \mathrm{rs}=0.14,95 \% \\
\text { CI: } 0.08-0.19) \text {. }\end{array}$ \\
\hline $\begin{array}{l}\text { (Oostenbach et } \\
\text { al., 2019) }\end{array}$ & $\begin{array}{l}\text { Propensity to select healthier foods is related to nutritional claims, which sometimes led to an increase in energy } \\
\text { intake and food consumption by consumers. }\end{array}$ \\
\hline $\begin{array}{l}\text { (Nardi et al., } \\
\text { 2019) }\end{array}$ & $\begin{array}{l}\text { Past behaviour had an effect on food choice intentions }(\mathrm{r}=0.341 ; \mathrm{p}=0.001) \text { and behaviour }(\mathrm{r}=0.386 ; \mathrm{p}=0.291) \text {. This } \\
\text { relation was weaker in higher age (MLowAGE }=0.505 ; \text { MHighAGE }=0.344, \mathrm{p}=0.05) \text {. The relationship between PBC } \\
\text { and behaviour was weaker among women (MLowGEN }=0.304 ; \text { MHighGEN=0.13, } \mathrm{p}=0.05) \text {. }\end{array}$ \\
\hline $\begin{array}{l}\text { (McGowan et al., } \\
\text { 2019) }\end{array}$ & Oral health has a positive relationship with healthy diet/nutrition outcome. \\
\hline (Li et al., 2019 & Nutritional education improves dietary behaviours. \\
\hline $\begin{array}{l}\text { (Devonport et al., } \\
\text { 2019) }\end{array}$ & Stress, depression, and sadness increase unhealthy eating behaviours. \\
\hline
\end{tabular}




\begin{tabular}{|c|c|}
\hline $\begin{array}{l}\text { (Clohessy et al., } \\
\text { 2019) }\end{array}$ & Job role, workplace food environment, and social aspects of the office influence eating behaviours at the workplace. \\
\hline $\begin{array}{l}\text { Wright et al., } \\
2018\end{array}$ & $\begin{array}{l}\text { Social identity affects policies or interventions that aim at improving healthy choices. Reduction of portion size may } \\
\text { be effective. }\end{array}$ \\
\hline $\begin{array}{l}\text { (Woodruff et al., } \\
\text { 2018) }\end{array}$ & $\begin{array}{l}\text { New retailers selling healthy food may result in modest short-term improvements in healthy diet behaviour among } \\
\text { adults }\end{array}$ \\
\hline $\begin{array}{l}\text { (Rahimi-Ardabili } \\
\text { et al., 2018) }\end{array}$ & Self-compassion may be beneficial for improving nutritional or eating behaviours and body image. \\
\hline (Hill et al., 2018) & $\begin{array}{l}\text { Relationship between stress and unhealthy eating behaviours among children (younger than } 12 \text { years old: Hedge's } g= \\
0.283, \mathrm{p}<0.001 \text { ) and older than } 12 \text { years old: Hedge's } \mathrm{g}=0.274, \mathrm{p}=0.001 \text { ). }\end{array}$ \\
\hline $\begin{array}{l}\text { (Hartmann-Boyce } \\
\text { et al., 2018) }\end{array}$ & Availability of foods plays an important role in improving health. \\
\hline $\begin{array}{l}\text { (Appleton et al., } \\
\text { 2018) }\end{array}$ & $\begin{array}{l}\text { Exposure to healthy food and the use of rewards increase healthy dietary behaviours (exposure 0.23, CI: 0.07-0.39; } \\
\text { reward 0.32, CI: } 0.15-0.50 \text { ). }\end{array}$ \\
\hline $\begin{array}{l}\text { (Amireault et al., } \\
2018)\end{array}$ & Interventions that last $\geq 17$ weeks ( $\geq 4$ months) are more likely to improve healthy eating behaviours. \\
\hline (Pitt et al., 2017) & $\begin{array}{l}\text { Availability, accessibility and affordability were identified as key determinants of healthy food choice within } \\
\text { community nutrition environments. }\end{array}$ \\
\hline (Kaur et al., 2017) & Foods health claims have an important effect on dietary choices (OR 1.75, CI: 1.60-1.91). \\
\hline $\begin{array}{l}\text { (Broers et al., } \\
2017 \text { ) }\end{array}$ & Nudging aimed at increasing healthy diet behaviour have a moderate significant effect $(\mathrm{d}=0.30)$. \\
\hline Allan et al., 2017 & Environmental change seemed to affect eating behaviour successfully. \\
\hline $\begin{array}{l}\text { (Abeykoon et al., } \\
\text { 2017) }\end{array}$ & ig food access at retailers does not show strong evidence of enhancing health-related behaviour. \\
\hline
\end{tabular}




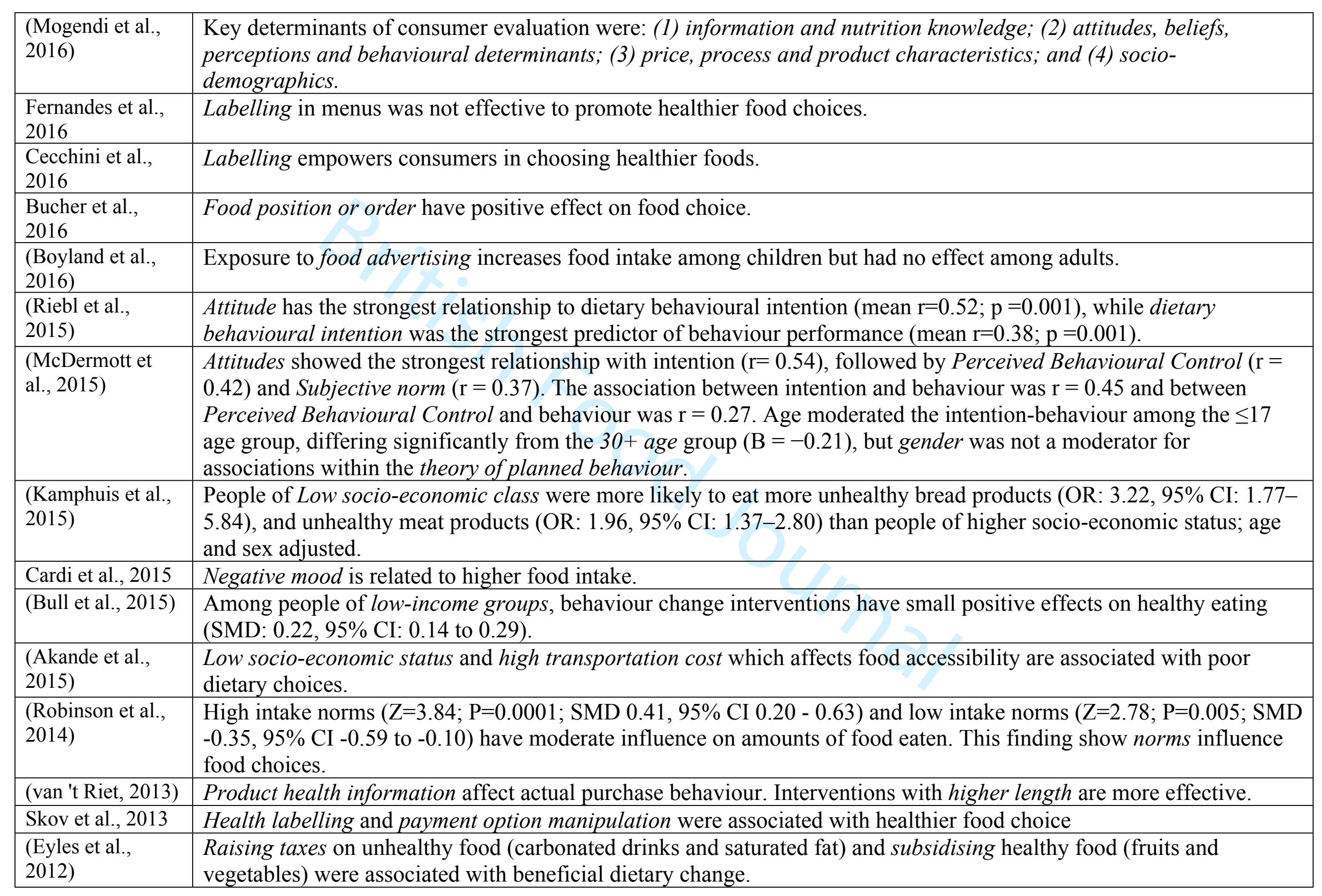




\begin{tabular}{|c|c|}
\hline $\begin{array}{l}\text { (Fletcher et al., } \\
\text { 2011) }\end{array}$ & $\begin{array}{l}\text { School friendships may be critical in eating behaviours and social-network based health promotion interventions in } \\
\text { schools are important. }\end{array}$ \\
\hline $\begin{array}{l}\text { (Diaz Ramirez et } \\
\text { al., 2011) }\end{array}$ & Relationship between exposure to food advertising and food consumption. \\
\hline $\begin{array}{l}\text { (Adriaanse et al., } \\
\text { 2011) }\end{array}$ & $\begin{array}{l}\text { Intention is an effective tool for promoting healthy food items (Cohen's } \mathrm{d}=0.51) \text {, but it is not a good tool for reducing } \\
\text { unhealthy eating patterns (Cohen's } \mathrm{d}=0.29) \text {. }\end{array}$ \\
\hline $\begin{array}{l}\text { (Andreyeva et al., } \\
2010)\end{array}$ & Reduction in income or dramatic increases in food prices can lead to changes in food purchasing behaviours. \\
\hline $\begin{array}{l}\text { (De Irala-Estevez } \\
\text { et al., 2000) }\end{array}$ & $\begin{array}{l}\text { Higher Socio-economic and educational status is associated with a healthy diet. The difference in fruit intake was } 24.3 \\
\text { g/person/day ( } 95 \% \text { confidence interval (CI) } 14.0-34.7) \text { between men in the highest and lowest level of education. } \\
\text { Similarly, the difference was } 33.6 \mathrm{~g} / \text { person/day for women }(95 \% \mathrm{CI}: 22.5-44.8) \text {. The differences regarding vegetables } \\
\text { were } 17.0 \mathrm{~g} / \text { person/day ( } 95 \% \mathrm{CI}: 8.6-25.5) \text { for men and } 13.4 \mathrm{~g} / \mathrm{person} / \text { day }(95 \% \mathrm{CI}: 7.1-19.7) \text { for women. The results } \\
\text { were still significantly different when occupation instead of education was used as an indicator of socio-economic } \\
\text { status. }\end{array}$ \\
\hline $\begin{array}{l}\text { (Spronk et al., } \\
2014)\end{array}$ & $\begin{array}{l}\text { Significant, positive, but weak }(\mathrm{r}<0.5) \text { association between higher nutritional knowledge and dietary intake, } \\
\text { especially with intake of fruit and vegetables. }\end{array}$ \\
\hline $\begin{array}{l}\text { (Escaron et al., } \\
\text { 2013) }\end{array}$ & $\begin{array}{l}\text { Supermarket and grocery store interventions (such as point-of-purchase, pricing, and promotion and advertising) for } \\
\text { promoting healthful eating is effective. }\end{array}$ \\
\hline $\begin{array}{l}\text { (Gittelsohn et al., } \\
\text { 2017) }\end{array}$ & $\begin{array}{l}\text { Pricing interventions that sought to improve access to healthy food increased stocking, sales, purchasing, and } \\
\text { consumption of these types of food. }\end{array}$ \\
\hline $\begin{array}{l}\text { (Liberato et al., } \\
\text { 2014) }\end{array}$ & Short-term monetary incentives increased purchase of healthier food. \\
\hline
\end{tabular}

Footnotes: SMD: standardized mean difference 
Table S3: Results of concepts from expert survey based on the intermediary conceptual framework

\begin{tabular}{|c|c|c|c|c|}
\hline No & $\begin{array}{l}\text { Level of } \\
\text { agreement with } \\
\text { the intermediary } \\
\text { model }\end{array}$ & $\begin{array}{l}\text { Concepts added to the } \\
\text { intermediary conceptual model }\end{array}$ & $\begin{array}{l}\text { Concepts removed from the } \\
\text { intermediary conceptual model }\end{array}$ & Other comments \\
\hline 1 & 4 & Health literacy & Not evident what attitude means & No \\
\hline 2 & 4 & $\begin{array}{l}\text { Subjective and moral norms, self- } \\
\text { identity, self-efficacy, self-esteem }\end{array}$ & $\begin{array}{l}\text { Perceived behavioural control and } \\
\text { social environment can influence } \\
\text { intention and behaviour directly }\end{array}$ & - \\
\hline 3 & 3 & $\begin{array}{l}\text { Food industry environment, } \\
\text { obesogenic environment, socio- } \\
\text { economic factors as part of the } \\
\text { social environment }\end{array}$ & $\begin{array}{l}\text { It is not only about the intention } \\
\text { and behaviour, and it is about } \\
\text { accessibility, which does not only } \\
\text { influence perceived control, as it } \\
\text { also impacts access to healthier or } \\
\text { less healthy foods beyond control. }\end{array}$ & - \\
\hline 4 & 3 & $\begin{array}{l}\text { Cooking skills (within perceived } \\
\text { control); habits and heuristics (as } \\
\text { food choices rely mostly on prior } \\
\text { experience). In the social } \\
\text { environment, you can address } \\
\text { choice architecture and obesogenic } \\
\text { facilitators. }\end{array}$ & $\begin{array}{l}\text { I think that your variable for } \\
\text { perceived control may not be the } \\
\text { best. Both are more about food } \\
\text { security. }\end{array}$ & $\begin{array}{l}\text { Your model seems to be an } \\
\text { adaptation of the theory of } \\
\text { planned behaviour. You } \\
\text { could enrich your model with } \\
\text { thinking of the dual-process } \\
\text { theory and how it may add } \\
\text { instrumental variables to your } \\
\text { model. }\end{array}$ \\
\hline 5 & 4 & $\begin{array}{l}\text { Wonder about personal food } \\
\text { preference, hunger, appetite, taste } \\
\text { preferences, social support, self- } \\
\text { efficacy, media and advertising? } \\
\text { They may fall under some of the } \\
\text { existing categories, but I think I } \\
\text { need to be included. }\end{array}$ & No & $\begin{array}{l}\text { This is a good source of info } \\
\text { although Europe focused - } \\
\text { https://www.eufic.org/en/heal } \\
\text { thy-living/article/the- } \\
\text { determinants-of-food-choice }\end{array}$ \\
\hline
\end{tabular}




\begin{tabular}{|c|c|c|c|c|}
\hline 6 & 3 & $\begin{array}{l}\text { Many food environments and food } \\
\text { system drivers, commercial } \\
\text { influences etc. }\end{array}$ & No & - \\
\hline 7 & 2 & $\begin{array}{l}\text { Self-efficacy in cooking and eating } \\
\text { healthy; weight/body fat }\end{array}$ & No & $\begin{array}{l}\text { I believe that individual } \\
\text { factors should be divided into } \\
\text { modifiable and not (i.e. } \\
\text { personal characteristics and } \\
\text { variables that can be } \\
\text { changed). Moreover, there are } \\
\text { unperceived attitudes, such as } \\
\text { pleasantness, the habit of } \\
\text { eating in a certain way, } \\
\text { familiarity. It is hard to } \\
\text { properly evaluate the } \\
\text { conceptual model without } \\
\text { reading the literature in which } \\
\text { it is based. }\end{array}$ \\
\hline 8 & 2 & $\begin{array}{l}\text { Preference, background, body } \\
\text { image, self-efficiency }\end{array}$ & $\mathrm{No}$ & - \\
\hline 9 & 5 & $\begin{array}{l}\text { Self-efficacy, healthy diet-related } \\
\text { skills }\end{array}$ & No & No \\
\hline 10 & 4 & $\begin{array}{l}\text { Intrinsic motivation; Cultural } \\
\text { factors }\end{array}$ & $\mathrm{No}$ & - \\
\hline 11 & 3 & $\begin{array}{l}\text { I think that human behaviour could } \\
\text { also be influenced by mental } \\
\text { representation and cognitive } \\
\text { schemes of interpretation of reality. }\end{array}$ & No & - \\
\hline 12 & 3 & $\begin{array}{l}\text { Not just social environment, but } \\
\text { culture (cf. vast differences } \\
\text { between countries); behavioural } \\
\text { biases (often not conscious: cf. } \\
\text { Pierre 'Chandon's articles) }\end{array}$ & No & $\begin{array}{l}\text { It is a good basis to explain it. } \\
\text { It can probably never be } \\
\text { exhaustive, but surely it can } \\
\text { help. }\end{array}$ \\
\hline
\end{tabular}




\begin{tabular}{|c|c|c|c|c|}
\hline 13 & 4 & $\begin{array}{l}\text { Maybe the current health status of } \\
\text { the individual as well as the health } \\
\text { status of family members. For } \\
\text { example, knowing that my father } \\
\text { had diabetes, I might follow a more } \\
\text { healthy diet to avoid getting } \\
\text { diabetes. }\end{array}$ & No & No \\
\hline 14 & 3 & Occupation, income & No & $\begin{array}{l}\text { The perceived control factors } \\
\text { would require further } \\
\text { digging. It can gather more } \\
\text { variables that are relevant }\end{array}$ \\
\hline 15 & 4 & $\begin{array}{l}\text { Familial aggregation and genetic } \\
\text { predisposition, co-morbidities }\end{array}$ & No & No \\
\hline 16 & 4 & $\begin{array}{l}\text { Does the model consider whether } \\
\text { or not individuals are motivated (by } \\
\text { health or other?) to make healthy } \\
\text { choices? Health status? } \\
\text { Background interests (e.g. a high } \\
\text { performing athlete might be more } \\
\text { likely to choose wisely). Impact of } \\
\text { media/advertising to influence? } \\
\text { Impact of peer pressure (all friends } \\
\text { going to McDonald's...) }\end{array}$ & No & No other \\
\hline 17 & 4 & $\begin{array}{l}\text { Time management as an individual } \\
\text { factor, and quality and social status } \\
\text { as perceived control }\end{array}$ & $\begin{array}{l}\text { What is the minimum age included } \\
\text { in this conceptual framework? If it } \\
\text { is } 18 \text { years, then you have left out } \\
\text { factors that influence this age } \\
\text { group? Yes, they are also } \\
\text { influenced by (social, economic, } \\
\text { physical, biological and attitudes, } \\
\text { belief and knowledge) But most } \\
\text { importantly taste hunger and } \\
\text { convenience. The prevalence of }\end{array}$ & $\begin{array}{l}\text { I would classify the factors in } \\
\text { a group (social, economic, } \\
\text { physical, biological and } \\
\text { attitudes, belief and } \\
\text { knowledge). All the best. }\end{array}$ \\
\hline
\end{tabular}




\begin{tabular}{|c|c|c|c|c|}
\hline & & & $\begin{array}{l}\text { obesity in this age group is } \\
\text { increasing rapidly. }\end{array}$ & \\
\hline 18 & 4 & $\begin{array}{l}\text { Perhaps something around physical } \\
\text { health. You have mental health, but } \\
\text { there are many physical conditions } \\
\text { the dictate how a diet should be or } \\
\text { be adapted. }\end{array}$ & No & $\begin{array}{l}\text { Just the consideration of } \\
\text { "physical health." }\end{array}$ \\
\hline 19 & 5 & $\begin{array}{l}\text { Diseases, drugs. Also, intermediate } \\
\text { results could significantly improve } \\
\text { the adherence to the diet. }\end{array}$ & No & $\begin{array}{l}\text { Some diseases can influence } \\
\text { adherence, as well as } \\
\text { smoking habits }\end{array}$ \\
\hline 20 & 5 & $\begin{array}{l}\text { One aspect I think you missed is } \\
\text { "the power of advertisement"; It is } \\
\text { the principle behind of television } \\
\text { and its mechanism to condition us } \\
\text { into buying some products over the } \\
\text { other. This is served upon us by our } \\
\text { modern society's consumerism } \\
\text { logic }\end{array}$ & $\begin{array}{l}\text { No, actually it is a well-performing } \\
\text { model. It highlights the majority of } \\
\text { the factors that may affect a man }\end{array}$ & - \\
\hline 21 & 4 & $\begin{array}{l}\text { Maybe cultural and economic } \\
\text { capital as Bourdieu mentioned }\end{array}$ & Maybe physical activities & - \\
\hline 22 & 4 & Not seemingly & - & $\begin{array}{l}\text { Family environment or } \\
\text { childhood behaviour or } \\
\text { similar variable also might } \\
\text { contribute to diet behaviour. }\end{array}$ \\
\hline 23 & 4 & $\begin{array}{l}\text { You may add time to the } \\
\text { "Perceived Control" box - eating a } \\
\text { healthier diet may take more time } \\
\text { (shopping, cooking) than eating an } \\
\text { unhealthy diet. Even if someone } \\
\text { wants to eat healthier, he/she may } \\
\text { have limited time. }\end{array}$ & No & - \\
\hline
\end{tabular}


Table S4. Changes made between conceptual frameworks

\begin{tabular}{|c|c|c|}
\hline Versions of models & Type of change & Change \\
\hline \multirow[t]{2}{*}{$\begin{array}{l}\text { Primary to } \\
\text { intermediary }\end{array}$} & Elements & $\begin{array}{l}\text { Environmental factors (Social and physical): change to Social Environment } \\
\text { Intention to a healthy diet: change to intention } \\
\text { Adherence to a healthy diet: change to the behaviour } \\
\text { Access to healthy foods: change to access } \\
\text { knowledge of a healthy diet: change to knowledge } \\
\text { Economic level: added } \\
\text { Perceived control: added } \\
\text { Food factors: removed } \\
\text { Quality (safety): removed } \\
\text { Taste: removed }\end{array}$ \\
\hline & Relations & $\begin{array}{l}\text { Past behaviour influencing intention: added } \\
\text { Past behaviour influencing social environment: added } \\
\text { Perceived control influencing intention to behaviour: added } \\
\text { Food factors influencing intention: removed } \\
\text { Food factors influencing intention to behaviour: removed }\end{array}$ \\
\hline \multirow[t]{2}{*}{$\begin{array}{l}\text { Intermediary to Final } \\
\text { model }\end{array}$} & Elements & $\begin{array}{l}\text { Access: change to accessibility } \\
\text { Time: added } \\
\text { Self-efficacy: added } \\
\text { Self-esteem: added }\end{array}$ \\
\hline & Relations & $\begin{array}{l}\text { Individual factors: divided into Demographic factors, individual dietary mind-set } \\
\text { factors, and Psychological and behavioural factors. }\end{array}$ \\
\hline
\end{tabular}




\section{Reference:}

Abeykoon, A. H., Engler-Stringer, R., \& Muhajarine, N. (2017). Health-related outcomes of new grocery store interventions: a systematic review. Public Health Nutr, 20(12), 2236-2248. doi:10.1017/s1368980017000933

Adriaanse, M. A., Vinkers, C. D. W., De Ridder, D. T. D., Hox, J. J., \& De Wit, J. B. F. (2011). Do implementation intentions help to eat a healthy diet? A systematic review and meta-analysis of the empirical evidence. Appetite, 56(1), 183-193. doi:10.1016/j.appet.2010.10.012

Akande, V. O., Hendriks, A. M., Ruiter, R. A., \& Kremers, S. P. (2015). Determinants of dietary behaviour and physical activity among Canadian Inuit: a systematic review. Int J Behav Nutr Phys Act, 12, 84. doi:10.1186/s12966-015-0252-y

Allan, J. L., Querstret, D., Banas, K., \& de Bruin, M. (2017). Environmental interventions for altering eating behaviours of employees in the workplace: a systematic review. Obesity Reviews, 18(2), 214-226. doi:10.1111/obr.12470

Amireault, S., Fong, A. J., \& Sabiston, C. M. (2018). Promoting Healthy Eating and Physical Activity Behaviours: A Systematic Review of Multiple Health Behaviour Change Interventions Among Cancer Survivors. American Journal of Lifestyle Medicine, 12(3), 184-199. doi: $10.1177 / 1559827616661490$

Andreyeva, T., Long, M. W., \& Brownell, K. D. (2010). The impact of food prices on consumption: a systematic review of research on the price elasticity of demand for food. Am J Public Health, 100(2), 216-222. doi:10.2105/ajph.2008.151415

Appleton, K. M., Hemingway, A., Rajska, J., \& Hartwell, H. (2018). Repeated exposure and conditioning strategies for increasing vegetable liking and intake: systematic review and meta-analyses of the published literature. Am J Clin Nutr, 108(4), 842-856. doi:10.1093/ajcn/nqy143

Bennett, R., Zorbas, C., Huse, O., Peeters, A., Cameron, A. J., Sacks, G., \& Backholer, K. (2020). Prevalence of healthy and unhealthy food and beverage price promotions and their potential influence on shopper purchasing behaviour: A systematic review of the literature. Obes Rev, 21(1), e12948. doi:10.1111/obr.12948

Blaga, O. M., Vasilescu, L., \& Chereches, R. M. (2018). Use and effectiveness of behavioural economics in interventions for lifestyle risk factors of non-communicable diseases: a systematic review with policy implications. Perspect Public Health, 138(2), 100-110. doi: $10.1177 / 1757913917720233$

Boyland, E. J., Nolan, S., Kelly, B., Tudur-Smith, C., Jones, A., Halford, J. C., \& Robinson, E. (2016). Advertising as a cue to consume: a systematic review and meta-analysis of the effects of acute exposure to unhealthy food and nonalcoholic beverage advertising on intake in children and adults. Am J Clin Nutr, 103(2), 519-533. doi:10.3945/ajen.115.120022

Broers, V. J. V., De Breucker, C., Van den Broucke, S., \& Luminet, O. (2017). A systematic review and meta-analysis of the effectiveness of nudging to increase fruit and vegetable choice. Eur J Public Health, 27(5), 912-920. doi:10.1093/eurpub/ckx085 
Bucher, T., Collins, C., Rollo, M. E., McCaffrey, T. A., De Vlieger, N., Van Der Bend, D., . . Perez-Cueto, F. J. A. (2016). Nudging consumers towards healthier choices: A systematic review of positional influences on food choice. British Journal of Nutrition, 115(12), $2252-2263$. doi:10.1017/S0007114516001653

Bull, E. R., Dombrowski, S. U., McCleary, N., \& Johnston, M. (2015). Are interventions for low-income groups effective in changing healthy eating, physical activity and smoking behaviours? a systematic review and meta-analysis. BMJ Open, 4(11). doi:10.1136/bmjopen-2014-006046

Cardi, V., Leppanen, J., \& Treasure, J. (2015). The effects of negative and positive mood induction on eating behaviour: A meta-analysis of laboratory studies in the healthy population and eating and weight disorders. Neuroscience and Biobehavioural Reviews, 57, $299-309$. doi:10.1016/j.neubiorev.2015.08.011

Cecchini, M., \& Warin, L. (2016). Impact of food labelling systems on food choices and eating behaviours: A systematic review and meta-analysis of randomized studies. Obesity Reviews, 17(3), 201-210. doi:10.1111/obr.12364

Clohessy, S., Walasek, L., \& Meyer, C. (2019). Factors influencing employees' eating behaviours in the office-based workplace: A systematic review. Obesity Reviews, 20(12), 1771-1780. doi:10.1111/obr.12920

De Irala-Estevez, J., Groth, M., Johansson, L., Oltersdorf, U., Prättälä, R., \& Martínez-González, M. A. (2000). A systematic review of socioeconomic differences in food habits in Europe: consumption of fruit and vegetables. European Journal of Clinical Nutrition, 54(9), 706-714.

Devonport, T. J., Nicholls, W., \& Fullerton, C. (2019). A systematic review of the association between emotions and eating behaviour in normal and overweight adult populations. Journal of Health Psychology, 24(1), 3-24. doi:10.1177/1359105317697813

Diaz Ramirez, G., Souto-Gallardo, M. C., Bacardi Gascon, M., \& Jimenez-Cruz, A. (2011). Effect of food television advertising on the preference and food consumption: systematic review]. Nutr Hosp, 26(6), 1250-1255. doi:10.1590/s0212-16112011000600009

Escaron, A. L., Meinen, A. M., Nitzke, S. A., \& Martinez-Donate, A. P. (2013). Peer reviewed: supermarket and grocery store-based interventions to promote healthful food choices and eating practices: a systematic review. Preventing Chronic Disease, 10.

Eyles, H., Ni Mhurchu, C., Nghiem, N., \& Blakely, T. (2012). Food pricing strategies, population diets, and non-communicable disease: a systematic review of simulation studies. PLoS Med, 9(12), e1001353. doi:10.1371/journal.pmed.1001353

Fernandes, A. C., Oliveira, R. C., Proenca, R. P. C., Curioni, C. C., Rodrigues, V. M., \& Fiates, G. M. R. (2016). Influence of menu labeling on food choices in real-life settings: A systematic review. Nutrition Reviews, 74(8), 534-548. doi:10.1093/nutrit/nuw013

Fletcher, A., Bonell, C., \& Sorhaindo, A. (2011). You are what your friends eat: Systematic review of social network analyses of young people's eating behaviours and bodyweight. Journal of Epidemiology and Community Health, 65(6), 548-555. doi:10.1136/jech.2010.113936 
Garcia, M. T., Ribeiro, S. M., Germani, A., \& Bogus, C. M. (2018). The impact of urban gardens on adequate and healthy food: a systematic review. Public Health Nutr, 21(2), 416-425. doi:10.1017/s1368980017002944

Gittelsohn, J., Trude, A. C. B., \& Kim, H. (2017). Peer Reviewed: Pricing Strategies to Encourage Availability, Purchase, and Consumption of Healthy Foods and Beverages: A Systematic Review. Preventing Chronic Disease, 14.

Hartmann-Boyce, J., Bianchi, F., Piernas, C., Payne Riches, S., Frie, K., Nourse, R., \& Jebb, S. A. (2018). Grocery store interventions to change food purchasing behaviours: a systematic review of randomized controlled trials. Am J Clin Nutr, 107(6), 1004-1016. doi:10.1093/ajcn/nqy045

Hill, D. C., Moss, R. H., Sykes-Muskett, B., Conner, M., \& O'Connor, D. B. (2018). Stress and eating behaviours in children and adolescents: Systematic review and meta-analysis. Appetite, 123, 14-22. doi:10.1016/j.appet.2017.11.109

Kamphuis, C. B. M., Jansen, T., Mackenbach, J. P., \& Van Lenthe, F. J. (2015). Bourdieu's cultural capital in relation to food choices: A systematic review of cultural capital indicators and an empirical proof of concept. PLoS ONE, 10(8). doi:10.1371/journal.pone.0130695

Kaur, A., Scarborough, P., \& Rayner, M. (2017). A systematic review, and meta-analyses, of the impact of health-related claims on dietary choices. Int J Behav Nutr Phys Act, 14(1), 93. doi:10.1186/s12966-017-0548-1

Li, X., Huang, Y., Yin, R., Pan, C., Cai, Y., \& Wang, Z. (2019). Visualized nutrition education and dietary behavioural change: A systematic review and meta-analysis. Crit Rev Food Sci Nutr, 59(12), 1976-1985. doi:10.1080/10408398.2018.1469466

Liberato, S. C., Bailie, R., \& Brimblecombe, J. (2014). Nutrition interventions at point-of-sale to encourage healthier food purchasing: a systematic review. BMC Public Health, 14(1), 919.

McDermott, M. S., Oliver, M., Svenson, A., Simnadis, T., Beck, E. J., Coltman, T., .. Sharma, R. (2015). The theory of planned behaviour and discrete food choices: A systematic review and meta-analysis. International Journal of Behavioural Nutrition and Physical Activity, 12(1). doi:10.1186/s12966-015-0324-z

McGowan, L., McCrum, L. A., Watson, S., Cardwell, C., McGuinness, B., Rutherford, H., .. McKenna, G. (2019). The impact of oral rehabilitation coupled with healthy dietary advice on the nutritional status of adults: A systematic review and meta-analysis. Crit Rev Food Sci Nutr, 1-21. doi:10.1080/10408398.2019.1630600

Mogendi, J. B., De Steur, H., Gellynck, X., \& Makokha, A. (2016). Consumer evaluation of food with nutritional benefits: a systematic review and narrative synthesis. Int J Food Sci Nutr, 67(4), 355-371. doi:10.3109/09637486.2016.1170768

Nardi, V. A. M., Jardim, W. C., Ladeira, W., \& Santini, F. (2019). Predicting food choice: a meta-analysis based on the theory of planned behaviour. British Food Journal, 121(10), 2250-2264. doi:10.1108/BFJ-08-2018-0504 
Oostenbach, L. H., Slits, E., Robinson, E., \& Sacks, G. (2019). Systematic review of the impact of nutrition claims related to fat, sugar and energy content on food choices and energy intake. BMC Public Health, 19(1). doi:10.1186/s12889-019-7622-3

Panao, I., \& Carraca, E. V. (2019). Effects of exercise motivations on body image and eating habits/behaviours: A systematic review. Nutr Diet. doi:10.1111/1747-0080.12575

Perez-Cueto, F. J. A. (2019). An umbrella review of systematic reviews on food choice and nutrition published between 2017 and-2019. Nutrients, 11(10). doi:10.3390/nu11102398

Pitt, E., Gallegos, D., Comans, T., Cameron, C., \& Thornton, L. (2017). Exploring the influence of local food environments on food behaviours: a systematic review of qualitative literature. Public Health Nutr, 20(13), 2393-2405. doi:10.1017/s1368980017001069

Rahimi-Ardabili, H., Reynolds, R., Vartanian, L. R., McLeod, L. V. D., \& Zwar, N. (2018). A Systematic Review of the Efficacy of Interventions that Aim to Increase Self-Compassion on Nutrition Habits, Eating Behaviours, Body Weight and Body Image. Mindfulness, 9(2), 388-400. doi:10.1007/s12671-017-0804-0

Riebl, S. K., Estabrooks, P. A., Dunsmore, J. C., Savla, J., Frisard, M. I., Dietrich, A. M., . . Davy, B. M. (2015). A systematic literature review and meta-analysis: The Theory of Planned Behaviour's application to understand and predict nutrition-related behaviours in youth. Eat Behav, 18, 160-178. doi:10.1016/j.eatbeh.2015.05.016

Robinson, E., Thomas, J., Aveyard, P., \& Higgs, S. (2014). What everyone else is eating: A systematic review and meta-analysis of the effect of informational eating norms on eating behaviour. Journal of the Academy of Nutrition and Dietetics, 114(3), 414-429. doi:10.1016/j.jand.2013.11.009

Robson, S. M., McCullough, M. B., Rex, S., Munafo, M. R., \& Taylor, G. (2020). Family Meal Frequency, Diet, and Family Functioning: A Systematic Review With Meta-analyses. J Nutr Educ Behav. doi:10.1016/j.jneb.2019.12.012

Sala, M., Rochefort, C., Lui, P. P., \& Baldwin, A. S. (2019). Trait mindfulness and health behaviours: a meta-analysis. Health Psychol Rev, 1-49. doi:10.1080/17437199.2019.1650290

Shaw, A. M., Wootton, S. A., Fallowfield, J. L., Allsopp, A. J., \& Parsons, E. L. (2019). Environmental interventions to promote healthier eating and physical activity behaviours in institutions: A systematic review. Public Health Nutrition, 22(8), 1518-1531. doi:10.1017/S1368980018003683

Skov, L. R., Lourenço, S., Hansen, G. L., Mikkelsen, B. E., \& Schofield, C. (2013). Choice architecture as a means to change eating behaviour in self-service settings: A systematic review. Obesity Reviews, 14(3), 187-196. doi:10.1111/j.1467-789X.2012.01054.x

Spronk, I., Kullen, C., Burdon, C., \& O'Connor, H. (2014). Relationship between nutrition knowledge and dietary intake. British Journal of Nutrition, 111(10), 1713-1726. 
Steinhauser, J., \& Hamm, U. (2018). Consumer and product-specific characteristics influencing the effect of nutrition, health and risk reduction claims on preferences and purchase behaviour - A systematic review. Appetite, 127, 303-323. doi:10.1016/j.appet.2018.05.012

Strahler, J. (2019). Sex differences in orthorexic eating behaviours: A systematic review and meta-analytical integration. Nutrition, 67-68. doi:10.1016/j.nut.2019.06.015

Tan, S. Y., \& Tucker, R. M. (2019). Sweet Taste as a Predictor of Dietary Intake: A Systematic Review. Nutrients, 11(1). doi: 10.3390/nu11010094

Tørris, C., \& Mobekk, H. (2019). Improving cardiovascular health through nudging healthier food choices: A systematic review. Nutrients, 11(10). doi:10.3390/nu11102520

van 't Riet, J. (2013). Sales effects of product health information at points of purchase: a systematic review. Public Health Nutr, 16(3), 418-429. doi:10.1017/s1368980012001103

Vecchio, R., \& Cavallo, C. (2019). Increasing healthy food choices through nudges: A systematic review. Food Quality and Preference, 78. doi:10.1016/j.foodqual.2019.05.014

Woodruff, R. C., Raskind, I. G., Harris, D. M., Gazmararian, J. A., Kramer, M., Haardorfer, R., \& Kegler, M. C. (2018). The dietary impact of introducing new retailers of fruits and vegetables into a community: results from a systematic review. Public Health Nutr, 21(5), 981-991. doi:10.1017/s1368980017003226

Wright, B., \& Bragge, P. (2018). Interventions to promote healthy eating choices when dining out: A systematic review of reviews. British Journal of Health Psychology, 23(2), 278-295. doi:10.1111/bjhp.12285

Yang, Y., Shields, G. S., Wu, Q., Liu, Y., Chen, H., \& Guo, C. (2019). Cognitive training on eating behaviour and weight loss: A meta-analysis and systematic review. Obesity Reviews, 20(11), 1628-1641. doi:10.1111/obr.12916

Yeung, A. W. K. (2018). Sex differences in brain responses to food stimuli: a meta-analysis on neuroimaging studies. Obes Rev, 19(8), 11101115. doi:10.1111/obr.12697

Zorbas, C., Palermo, C., Chung, A., Iguacel, I., Peeters, A., Bennett, R., \& Backholer, K. (2018). Factors perceived to influence healthy eating: a systematic review and meta-ethnographic synthesis of the literature. Nutrition Reviews, 76(12), 861-874. doi:10.1093/nutrit/nuy043 


\section{Supplementary material}

Figure S1. Initial conceptual framework.

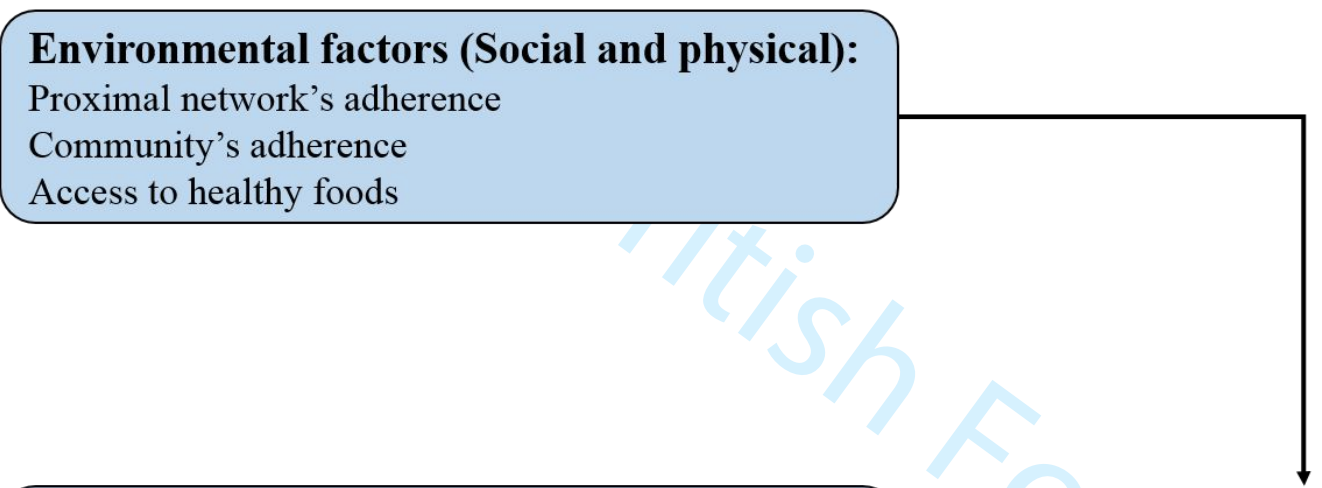

\section{Individual factors:}

Attitude, Age, Gender, Educational levels, Physical activity, Knowledge to healthy diet, Psychological factors (Depression and Stress)

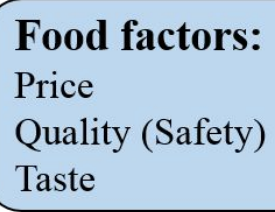


Figure S2. Intermediary conceptual framework.

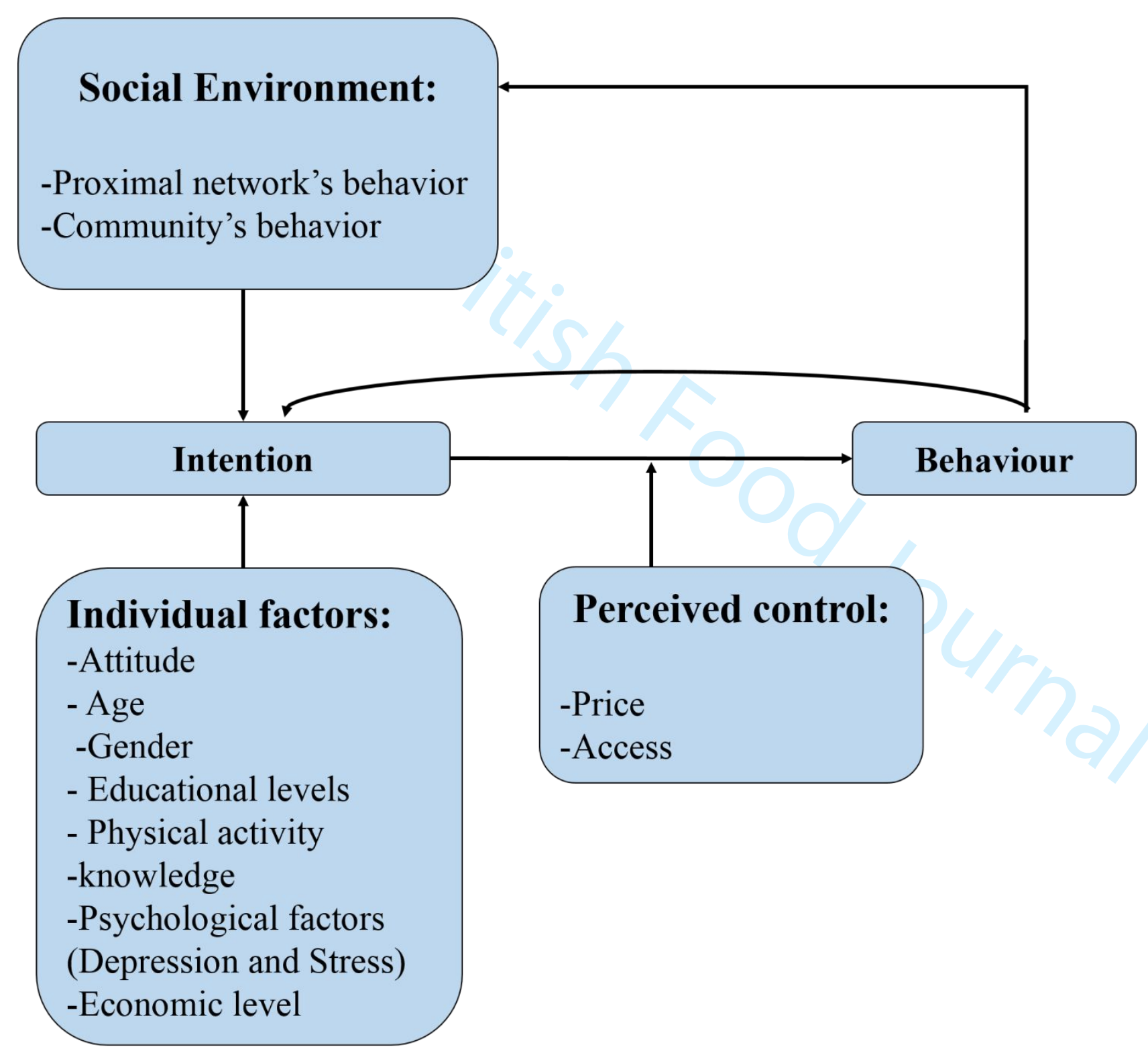


Figure S3. Frequency (\%) of variables proposed by expert researchers.

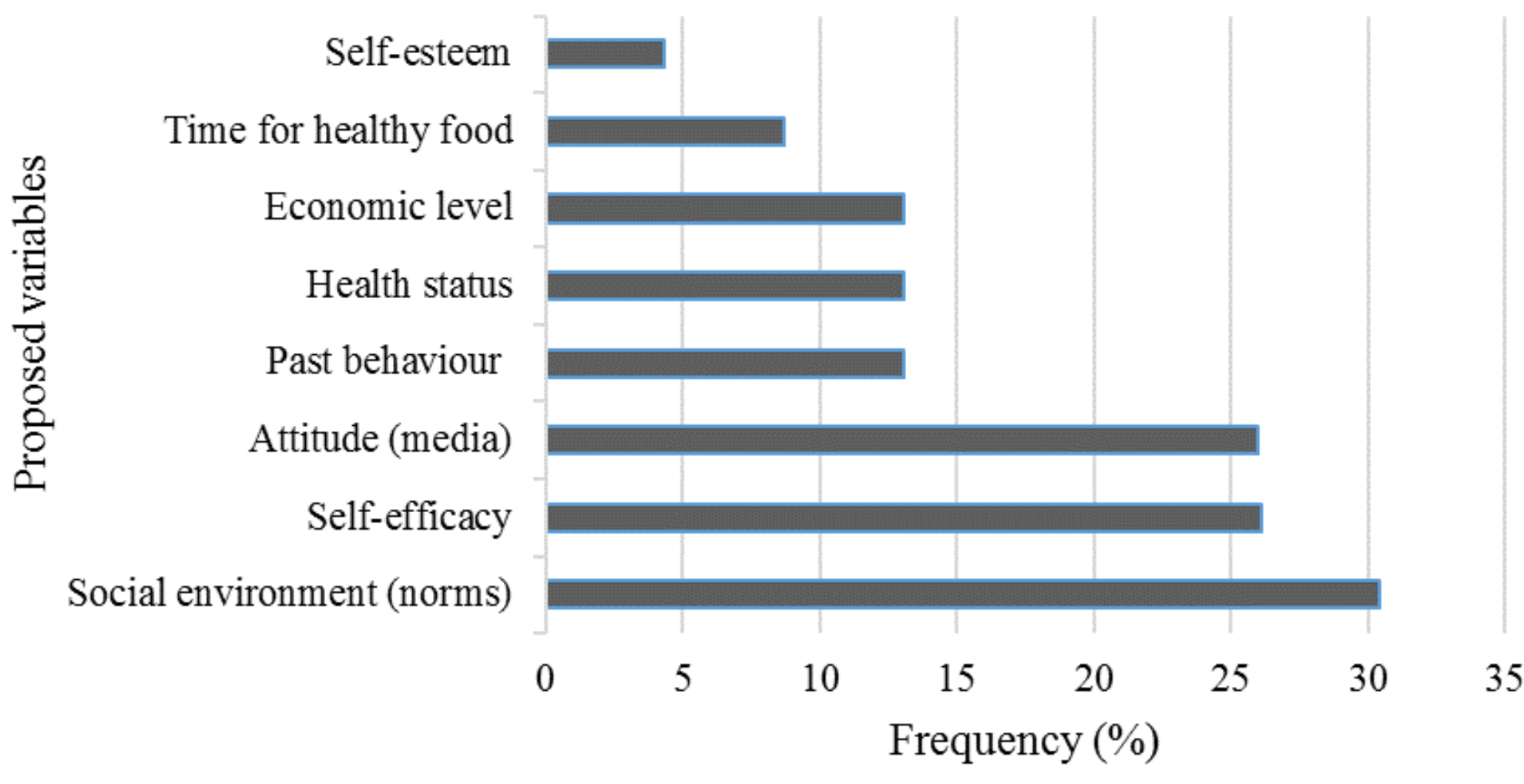

